Peter Sean Lie, Anak Agung Banyu Perwita | The Modi Factor: The Role Of Narendra Modi's Idiosyncratic Factors In India's Foreign Policy Responses Towards China Pakistan Economic Corridor

Article

\title{
The Modi Factor: The Role Of Narendra Modi's Idiosyncratic Factors In India's Foreign Policy Responses Towards China Pakistan Economic Corridor
} Peter Sean Lie ${ }^{1}$, Anak Agung Banyu Perwita ${ }^{2}$

${ }^{1}$ International Relations Department, President University, Indonesia

${ }^{2}$ President Center for International Studies, Indonesia

\section{SUBMISSION TRACK}

$\begin{array}{ll}\text { Recieved } & : \text { 05 February } 2019 \\ \text { Final Revision } & : \text { 03 September } 2019 \\ \text { Available Online } & : \text { 30 November } 2019\end{array}$

KEYWORD

Belt and Road Initiative, Sino-Indian Relations, India Foreign Policy, Narendra Modi, foreign policy analysis

KATA KUNCI

Belt and Road Initiative, Hubungan Tiongkok India, Kebijakan Luar Negeri India, Narendra Modi, Analisis Kebijakan Luar Negeri

\section{CORRESSPONDENCE}

E-mail : aabanyu.perwita@gmail.com

\section{A B S T R A C T}

The development of the China-Pakistan Economic Corridor (CPEC), as part of the Belt and Road Initiative (BRI), is one of the causes of worsening Sino-Indian relations in recent years. Seeing the possible worsening relations, India initiated to invite Xi Jinping for an Informal Summit with Narendra Modi. With a longstanding historical relationship with China, and his personal style diplomacy, Modi manages to fix some misconception with Xi Jinping on several issues. While trying to fix Sino-Indian relations, Narendra Modi is at the same time still firm on its opposition towards the Project. This article aims at examining the idiosyncratic factors of Narendra Modi in India's foreign policy in responding toward CPEC. The authors observed that Narendra Modi's personality plays a big role in India's response towards China-Pakistan Economic Corridor. Modi's strong and assertive personality, coupled with his Hindu-nationalist belief, explained the Indian decision to firmly opposing the CPEC. On the other hand, the footprints of Modi's charisma, personal-style diplomacy, and his longstanding relationship with China, are visible in the Wuhan Summit, in which Modi became the spearhead of diplomacy.

\section{A B S T R A K}

Perkembangan China-Pakistan Economic Corridor (CPEC) sebagai bagian dari Belt and Road Initiative (BRI) merupakan salah satu penyebab memburuknya hubungan Tiongkok dengan India dalam beberapa tahun terakhir. Koridor ekonomi dijalankan melalui Kashmir yang diduduki. Melihat kemungkinan memburuknya hubungan, India berinisiatif mengundang XI Jinping untuk KTT Informal dengan Narendra Modi. Dengan hubungan historis yang sudah lama dengan Tiongkok dan diplomasi pribadinya, Modi berhasil memperbaiki beberapa kesalahpahaman dengan Xi Jinping. Ketika mencoba untuk memperbaiki hubungan Tiongkok-India, Narendra Modi pada saat yang sama masih teguh pada penentangannya terhadap proyek. Artikel ini bertujuan untuk meneliti faktor-faktor istimewa Narendra Modi dalam kebijakan luar negeri India dalam menanggapi CPEC. Penulis mengamati bahwa kepribadian Narendra Modi memainkan peran besar dalam respon India terhadap CPEC. Kepribadian Modi yang kuat dan tegas, ditambah dengan kepercayaan nasionalis Hindu nya menjelaskan keputusan India untuk secara tegas menentang CPEC. Disisi lain, kharisma Modi, diplomasi personal serta hubungan lama dengan Tiongkok terlihat dalam KTT Wuhan dimana Modi menjadi ujung tombak diplomasi 


\section{Introduction}

Sino-Indian relations entered a new era since Narendra Modi took the office in 2014. He effortlessly expressed his admiration towards China. Even before he was sworn as Prime Minister of India, Modi has visited the Middle Kingdom as Chief Minister of the State of Gujarat. In the visit, he stated:

"China and its people have a special place in my heart, I admire their hardworking, disciplined and resilient nature and above all, their sense of history. Our cultural bonds are very strong and deep-rooted. Over the years, our relations have further strengthened. We are committed to making them still better, fruitful and productive.",

Just a few days after being the Prime Minister, Narendra Modi quickly invited Xi Jinping to visit India, where 16 MoUs were signed by both countries. ${ }^{2}$ The two leaders also met at BRICS Summit in Brazil, July 2015. An uninterrupted 80-minute talk happened between the two leaders, and some major takeaways from the talk are: $\mathrm{Xi}$ Jinping invited India to be the founding member of the Asian Infrastructure Investment Bank, Modi requested for more Chinese investment in India's infrastructural sector. ${ }^{3}$

\footnotetext{
${ }^{1}$ K. J. Varma (2011, November 9). Narendra Modi seeks Chinese Investments. Retrieved from Livemint: https://www.livemint.com/Politics/jEg5QSoptBPRe mtqXWsV5K/Narendra-Modi-seeks-Chineseinvestments.html

${ }^{2}$ Indian Ministry of External Affairs. (2014, September 18). List of Documents signed during the State Visit of Chinese President Xi Jinping to India. Retrieved December 17, 2018, from Indian Ministry of External Affairs:

https://www.mea.gov.in/bilateral-

documents.htm?dtl/24012/List+of+Documents+sign ed+during+the+State+Visit+of+Chinese+President+ $\mathrm{Xi}+$ Jinping+to+India

${ }^{3}$ Chandrasekar \& MacAskill (2014, July 15).

Narendra Modi, Xi Jinping pledge to resolve IndiaChina border dispute. Retrieved from Livemint:
}

However in 2013, China started to promote its megaproject Belt and Road Initiative (BRI), a multibillion dollar connectivity projects with massive infrastructure investment covering land routes and maritime routes in order to boost trade relationship between China and the countries involved. ${ }^{4}$ One of its flagship projects under the big umbrella of BRI is the China Pakistan Economic Corridor (CPEC), a bilateral cooperation of connectivity between China and Pakistan. The economic corridor will connect Xinjiang Province in China to Gwadar port in Pakistan, a geo-strategically important port at the mouth of the Persian Gulf connecting Central Asia, South Asia and the Middle East. Along the way, the economic corridor will go through Pakistan occupied Kashmir, a long disputed area that India still claims until today. India considers this as a violation of its sovereignty and territorial integrity, and the country has stated its opposition towards the Project in numerous occasions.

China has been largely silent and gave a very few responses towards India's concern. Beijing's silence has been pointed out by Indian Ambassador to China, Gautam Bambawale, saying that China should not ignore this issue and starting to pay a serious attention to it. ${ }^{5}$ In response to the statement of Gautam Bambawale,

https://www.livemint.com/Politics/7kuzKNe9PW3T ND0AY13uYJ/Narendra-Modi-meets-Chinesepresident-Xi-Jinping-ahead-of-Br.html

${ }^{4}$ Baker McKenzie. (2017). Belt \& Road: the

Prospects and Perils of Building China's New Silk Road. Baker McKenzie.

${ }^{5}$ S. Dasgupta (2018, January 27). China should not ignore India's CPEC concerns: India Ambassador Gautam Bambawale. Retrieved from The Times of India: https://timesofindia.indiatimes.com/world/china/chi na-should-not-ignore-indias-cpecconcerns/articleshow/62667036.cms 
Chinese Foreign Ministry spokesperson Hua Chunying defended the CPEC, saying that, “... CPEC is a project for economic cooperation, pure and simple. It involves no territorial disputes and targets no third parties." In other words, Hua denies that CPEC violates India's sovereignty. Another public statement came from $\mathrm{Xi}$ Jinping himself, saying that the CPEC is targeted to spur peace and development and those who oppose this will "never succeed."7 Although not directly mentioned, Xi Jinping obviously referred to India in this case, as India is the most outspoken opposition of the BRI and CPEC.

This tension has led to a worsening bilateral relation between the Elephant and the Panda. Ivan Lidarev wrote in the Diplomat that 2017 is a "tough year for China-India relations" and India's decision to oppose the Project is one of the major contributing factors. ${ }^{8}$ In a hearing on 'Worldwide Threat Assessment,' Dan Coats, the US National Intelligence Director stated argued that Sino-India ties would remain tense and possibly worsen further. ${ }^{9}$ According to Asia Times, these

\footnotetext{
${ }^{6}$ Hua Chunying. (2018, January 29). Foreign Ministry Spokesperson Hua Chunying's Regular Press Conference on January 29, 2018. Retrieved from Ministry of Foreign Affairs of the People's Republic of China:

https://www.fmprc.gov.cn/mfa_eng/xwfw_665399/s 2510_665401/t1529951.shtml

${ }^{7}$ Press Trust of India. (2018, September 20). Those who oppose BRI, CPEC will never succeed: Xi to Pakistan Army Chief. Retrieved January 7, 2019, from The Times of India:

https://timesofindia.indiatimes.com/world/china/tho se-who-oppose-bri-cpec-will-never-succeed-xi-tobajwa/articleshow/65887915.cms

${ }^{8}$ Lidarev, I. (2018, January 4). 2017: A Tough Year for China-India Relations. Retrieved from The Diplomat: https://thediplomat.com/2018/01/2017-atough-year-for-china-india-relations/

${ }^{9}$ M. Kugelman. (2018, February 18). Why IndiaChina ties are under strain. Retrieved from Arab News: http://www.arabnews.com/node/1249021
}

worsening India-China ties might end up with 'damages' to both countries. ${ }^{10}$ This worsening situation is briefly visible when China asked India to formally support 'One China' policy, but India declined and in turn stated that Beijing needed to stop the CPEC; India is under the impression that China has not made significant move to address the concern. ${ }^{11}$

Seeing the potential worsening situation between India and China, Narendra Modi took an initiative to visit China in order to have an informal summit with $\mathrm{Xi}$ Jinping. This rather surprising diplomatic move, deemed as "bold" by both Chinese and Indian media, is an effort to better both countries' relationship. ${ }^{12}$ Despite its informal nature, the summit has talked about various issues from global, regional, and bilateral matters, and most importantly the issue also touched some of the most pressing problems that the two countries experienced. ${ }^{13}$ In this summit,

\footnotetext{
${ }^{10}$ Tripathi, S. (2017, August 23). Worsening IndiaChina relations may lead to damage to both nations. Retrieved January 18, 2019, from Asia Times: http://www.atimes.com/worsening-india-chinarelations-may-lead-damage-nations/

${ }^{11}$ Chaudhury, D. R. (2018, June 7). Stop working in Pakistan-occupied Kashmir, says India after being urged to back 'One China'. Retrieved from The Economic Times:

https://economictimes.indiatimes.com/news/defence /stop-work-in-pakistan-occupied-kashmir-saysindia-after-being-urged-to-back-onechina/articleshow/64500030.cms

${ }^{12}$ Krishnan, A. (2018, April 23). Modi - Xi Meet: Rewards and Risks in PM's 'bold' diplomatic move. Retrieved from India Today: https://www.indiatoday.in/world/story/wuhansummit-rewards-and-risks-in-modi-s-bolddiplomatic-move-1217933-2018-04-23

13 Times of India. (2018, April 28). Modi-Xi's Informal Summit ends: Key takeaways. Retrieved from The Times of India: https://timesofindia.indiatimes.com/india/modi-xisinformal-summit-ends-5-keytakeaways/articleshow/63950531.cms
} 
Modi also initiated to invite Xi Jinping for another informal summit in India in 2019, a gesture showing that Modi does not want to lose the momentum of cooperation between the two countries. ${ }^{14}$ Brookings has labeled Wuhan Summit "an important signal of intent by India and China.", 15

However, despite the trend of cooperation, India is still firm on its opposition of the BRI and CPEC. Indian senior government official stated at Hindustan Times that, "we will deepen the areas of convergence (with China), but we will continue to hold on to our core interests and positions." 16 In other words, India is still very much concerned on its core interests of territorial integrity and sovereignty and there is no sign on giving compromise on CPEC. This relationship is described as an anomaly resulting from strategic and economic interests; India's strategic and core concern is being violated by China but at the same time China is an important economic partner for India. ${ }^{17}$

\footnotetext{
${ }^{14}$ Press Trust of India. (2018, April 27). Narendra Modi, Xi Jinping hold talks during informal Wuhan meeting. Retrieved from Livemint: https://www.livemint.com/Politics/6oEdw2MN9Uk kKyP1PBiU7O/Narendra-Modi-Xi-Jinping-holdtalks-during-informal-Wuhan-m.html

${ }^{15}$ S. Godbole (2018, May 23). Wuhan Summit: An Important signal of intent by India and China. Retrieved from Brookings: https://www.brookings.edu/blog/upfront/2018/05/23/wuhan-summit-an-importantsignal-of-intent-by-india-and-china/

${ }^{16}$ P. Jha (2018, November 22). India working to 'recalibrate' ties with China, but will not sign on to Belt and Road Initiative. Retrieved from Hindustan Times: https://www.hindustantimes.com/indianews/india-working-to-recalibrate-ties-with-chinabut-will-not-sign-on-to-belt-and-roadinitiative/story-iTunr71 mCRbXkVvHcxo29K.htm ${ }^{17}$ K. Pethiyagoda (2017, October 13). China-India relations: Millennia of peaceful coexistence meet modern day geopolitical interests. Retrieved from Brookings: https://www.brookings.edu/blog/orderfrom-chaos/2017/10/13/china-india-relations-
}

Looking at India's response and stance to China's CPEC project, it is necessary to closely examine the national leader's role and his leadership characteristics in making decisions. Prime Minister Narendra Modi has shown a bold move to not sending any representative to the Belt and Road Forum, while deciding to later try to fix both countries' relationship. It will be interesting to see Narendra Modi's leadership characteristics and his personality play a role in shaping India's decision, which people have been describing as "courageous, charismatic, and discipline." 18 It will also be interesting to look into the distinctive and unique "Modi Doctrine" and its correlation in India's foreign policy responses towards China's CPEC.

Be advised that the following discussion only focuses on the role of Modi's idiosyncratic factors in India's foreign policy responses towards CPEC. This means that the authors do not claim a causal-effect argument that Modi's idiosyncratic factors are the one influencing India's foreign policy responses in this case. The impact of India's foreign policy responses to the international world will also not become a concern in this discussion.

Thus, firstly the authors would see Modi's idiosyncratic factors, namely personality, experience, and belief/ideology. In this first part, a look on Modi's life and experience as a politician is crucial to see how he developed his personal traits. Secondly, the authors will

millennia-of-peaceful-coexistence-meet-modernday-geopolitical-interests/

18 The Economic Times. (2014, August 28). 5 Traits which make PM Narendra Modi stand out.

Retrieved from The Economic Times:

https://economictimes.indiatimes.com/slideshows/pe ople/5-traits-which-make-pm-narendra-modi-standout/slideshow/41051339.cms 
Peter Sean Lie, Anak Agung Banyu Perwita | The Modi Factor: The Role Of Narendra

Modi's Idiosyncratic Factors In India's

Foreign Policy Responses Towards China

Pakistan Economic Corridor

see the dynamics of Sino-Indian relations after the CPEC project surfaced. Thirdly, the authors analyze India's foreign policy responses towards CPEC and how Modi's idiosyncratic factors play a role in it.

\section{Research Method}

This research paper employs qualitative or interpretive method to acquire and understanding the process of India's foreign policy decision making and the role of individual leader in influencing the foreign policy decision. Qualitative method is the choice for this research paper because the authors focused on the understanding on how Narendra Modi's idiosyncrasy correlates the process of India's foreign policy a particular case. It also utilized analytical-descroptive metod to cover the relevant variables and details of the topic. In supporting the arguments, it employed empirical analysis on both primary and secondary sources. For the primary sources, it utilized Narendra Modi's documented speeches, Indian government official documents, Indian government websites, and national mass media release. Secondary sources were taken from related books and journals to support the arguments.

\section{Narendra Modi's Background}

Rose from a humble beginnings, Modi's ambitions and visions led him to a great political career as the longest-serving Chief Minister of Gujarat and ultimately the Prime Minister of India. His outstanding qualities of leadership is the by-product of over 60 years of his life journey, starting from his childhood to his political career. Modi's biographer, Mukhopadhyay describes him as "charismatic, extremely hard working person, a good administrator by extremely

\footnotetext{
${ }^{19}$ N. Mukhopadhyay (2013). Narendra Modi: The Man, the Times. New Delhi: Tranquebar Press.
}

\footnotetext{
${ }^{20}$ BJP. (2018). The Common Man who became the Prime Minister of India - Narendra Modi. Retrieved from Bharatiya Janata Party: http://www.bjp.org/leadership/shri-narendra-modi ${ }^{21}$ The Economic Times. (2018, September 17). Narendra Modi: Childhood Tales that Foretold the Coming of a Remarkable Leader. Retrieved December 3, 2018, from The Economic Times: https://economictimes.indiatimes.com/news/politicsand-nation/you-will-find-pm-modi-in-the-life-ofchild-narendra/articleshow/65839863.cms
} 
students. ${ }^{22} \mathrm{He}$ is an outspoken bold young boy, but at the same time he pays great respect to older people and his teachers. One of Modi's teachers, Prahlad Patel, described Modi as an exceptionally respectful student with a personal touch. ${ }^{23}$

In school, Narendra Modi was a member of the National Cadet Corps (NCC), a place that shaped his nationalism and patriotism. Recalling his days as young NCC cadet, Modi said that being a cadet not only grows patriotism, but also "helps one understand India better." 24 Not only $\mathrm{NCC}$, in his youth Modi was involved in the Rashtriya Swayamsevak Sangh (RSS), an extremely disciplined Hindu nationalist organization that further intensified his love and respect for the country. His dedication and determination helped him accelerated in the RSS hierarchy, as his involvement in this organization would helped him in his future political career. Not only active in organizations, Modi was talented in debating, speech, and rhetoric skills, which has shaped his public communication skills since an early age. Dr Bindeshwar Pathak, author of Modi's biography the Making of a Legend, described Modi as "quick-witted and logical." 25

\footnotetext{
${ }^{22}$ The Times of India. (2014, September 5). Encourage students to think about naton, PM Narendra Modi tells teachers. Retrieved December 3, 2018, from The Times of India: https://timesofindia.indiatimes.com/india/Encourage -students-to-think-about-nation-PM-NarendraModi-tells-teachers/articleshow/41761096.cms ${ }^{23}$ B. Pathak (2017). The Making of a Legend: Narendra Damodardas Modi. New Delhi: Sulab International Center for Action Sociology.

${ }^{24}$ R. Chatterjee (2016, July 15). When Prime Minister Narendra Modi was a Young NCC Cadet. Retrieved December 3, 2018, from Huffington Post: https://www.huffingtonpost.in/2015/01/29/modincc_n_6568430.html

${ }^{25}$ Ibid., The Making of a Legend: Narendra

Damodardas Modi. New Delhi: Sulab International Center for Action Sociology.
}

He began his first step in mainstream political career in 1987 by joining Bharatiya Janata Party (BJP). His first-ever task is to lead the campaign for Ahmedabad civic polls, which resulted in victory for BJP. Since then, Modi has kept his great reputation for being a highly effective campaign organizer, leading to BJP's victory in Gujarat in 1995. BJP Official Website praised Modi for being the "master strategist" behind the victory of BJP in Gujarat in 1995 and the years proceeding. ${ }^{26}$ His excellent track record has resulted in his quick ascend in the party hierarchy as the party's National Secretary in 1995, and not so long later appointed as BJP's General Secretary in 1998 by BJP's president at that time Khushabhau Thakre. ${ }^{27}$

Eventually he was promoted to Chief Minister of the State of Gujarat. As the leader of one of the biggest states in India, Modi has kept his leadership style with charisma and personal touch when dealing with people. Mukhopadhyay, Narendra Modi's biographer once had the chance to interview Modi in 2012. Mukhopadhyay was amazed by the unforgettable warmth of Modi's greetings, saying that, "as I walked into his office, he made me forget that I had come to meet the chief minister of a significant state and that he was a political leader of considerable eminence." His down-to-earth and personal style of building relations was apparent when he became good friends with Japanese Prime Minister Shinzo Abe, which helped him in the future when he became Prime Minister and wanted to

\footnotetext{
${ }^{26}$ BJP. (2017). Shri Narendra Modi. Retrieved December 4, 2018, from Bharatiya Janata Party: http://www.bjp.org/leadership/shri-narendra-modi ${ }^{27}$ N. Mukhopadhyay (2013). Narendra Modi: The Man, the Times. New Delhi: Tranquebar Press.
} 
Peter Sean Lie, Anak Agung Banyu Perwita | The Modi Factor: The Role Of Narendra

Modi's Idiosyncratic Factors In India's

Foreign Policy Responses Towards China

Pakistan Economic Corridor

secure bullet train project with Japan. ${ }^{28}$ Reaching a personal-level relationship with other people, and in this case with other world leader, is what Modi is good at.

Since becoming the Chief Minister of Gujarat, Modi has been internationally known as the man behind Gujarat's great economic achievements. He has also visited several countries while becoming Chief Minister, and one notable example is when he visited China in November 2011. Modi's official website described this visit as "historical" and "a great success," noting that many projects and proposals in the economic sector being discussed and planned. $^{29}$ During his campaign period, Modi rarely mentioned about foreign policy, due to his focus on domestic economic development, but he always believed in the balance between shanti (peace) and shakti (power) in executing foreign policy by optimizing diplomacy and building up India's military. His speech is his rally at Chennai in 2013 addressed his opinion on foreign policy, where he envisioned to have a "grand design for achieving 'India's century' through a balance between the high road of peace

\footnotetext{
${ }^{28}$ Chaudhury, D. R. (2018, April 26). Modi's personal touch to diplomacy furthers Indian interests worldwide . Retrieved December 13, 2018, from The Economic Times:

https://economictimes.indiatimes.com/news/politicsand-nation/modis-personal-touch-to-diplomacyfurthers-indian-interestsworldwide/articleshow/63930507.cms

${ }^{29}$ Narendra Modi Official Website. (2011, November 13). Gujarat Chief Minister Mr. Narendra Modi's Historic Visit to the People's Republic of China. Retrieved December 12, 2018, from Narendra Modi Official Website: https://www.narendramodi.in/gujarat-chief-ministermr-narendra-modi\%E2\%80\%99s-historic-visit-tothe-people $\%$ E2\%80\%99s-republic-of-china-4188
}

\section{and a no-nonsense toughness towards threats to national security."30 \\ India's Foreign Policy under Narendra Modi}

When taking India's highest office, Modi has kept his foreign policy principles of balancing peace and power by optimizing diplomacy and building up India's military. In this regard, Modi has arguably established a more proactive foreign policy compared to his predecessor, said Foreign secretary S. Jaishankar, quoted in the Diplomat. ${ }^{31}$ In many occasions he stated that he wants India to be more proactive, meaning to contribute more to the world, and the most recent one is when Modi spoke in 2018 World Economic Forum, saying that he and the government "seeks bigger global role for India." 32 In contrast with a reactive foreign policy, a proactive foreign policy is signalled by a more active role in world affairs, through more enhanced diplomacy in bilateral and multilateral stage and taking bigger role in solving world problems. ${ }^{33}$

\footnotetext{
${ }^{30}$ Indo Asian News Service. (2013, October 18).

Build foreign policy on culture, economy, security:

Modi. Retrieved December 12, 2018, from https://news.yahoo.com/build-foreign-policyculture-economy-security-modi-152803353.html

${ }^{31}$ P. Parameswaran (2015, July 21). A New

'Proactive' Indian Foreign Policy under Modi? Retrieved from The Diplomat:

https://thediplomat.com/2015/07/is-india-advancinga-new-proactive-foreign-policy-under-modi/

${ }^{32}$ A. Nag (2018, January 23). In Davos Debut, PM Modi Seeks Bigger Global Role For India.

Retrieved December 13, 2018, from NDTV: https://www.ndtv.com/india-news/davos-2018-pmnarendra-modi-seeks-bigger-global-role-for-india1803573

${ }^{33}$ D. Cheong (2018, January 10). China's foreign policy more proactive under Xi: Expert. Retrieved December 17, 2018, from The Straits Times: https://www.straitstimes.com/asia/east-asia/chinasforeign-policy-more-proactive-under-xi-expert
} 
Peter Sean Lie, Anak Agung Banyu Perwita | The Modi Factor: The Role Of Narendra

Modi's Idiosyncratic Factors In India's

Foreign Policy Responses Towards China

Pakistan Economic Corridor

In terms of diplomacy, Modi has kept India's diplomatic priority 'Neighborhood First' as one of the main agenda of Indian foreign policy, according to Indian Ministry of External Affairs (MEA) official document Breakthrough Diplomacy. ${ }^{34}$ This policy is apparent in Modi's first day as Prime Minister, as he met with the leaders of South Asian Association for Regional Cooperation (SAARC) nations. This meeting has signalled a new commitment from the new government to forge partnership in the region and that India would assume "a more pro-active role as a regional and global player." 35

India's next diplomatic priority is the Asia-Pacific countries through its 'Look East' policy enacted since 1991. Modi not only continue this policy, but modified the policy into 'Act East' policy, an upgraded version that he announced in the IndiaASEAN Summit in Myanmar. In his opening speech at that Summit, Modi has conveyed a clear message that 'Act East' is not only just rebranding, but a "more committed India to play a more active and prominent strategic role, exemplified by enhanced diplomacy in East and Southeast Asia." ${ }^{36}$ The 'Act East' policy has been apparent in Modi's first year as Prime Minister, with deeper engagement and

\footnotetext{
${ }^{34}$ Indian Ministry of External Affairs. (2015).

Breakthrough Diplomacy. Retrieved December 12, 2018, from Indian Ministry of External Affairs: http://mea.gov.in/Images/pdf/Breakthroughdiplomac y.pdf

${ }^{35}$ Indian Ministry of External Affairs. (2014). Fast Track Diplomacy. Retrieved December 12, 2018, from Indian Ministry of External Affairs: https://www.mea.gov.in/Uploads/PublicationDocs/2 3979_MEA-Brochure-6thSep2014-RE-LR.pdf ${ }^{36}$ Narendra Modi (2014, November 12). Opening Statement by Prime Minister at the 12th IndiaASEAN Summit. Retrieved December 12, 2018, from Indian Ministry of External Affairs: http://www.mea.gov.in/incoming-visitdetail.
}

high-level interactions with China, Japan, ASEAN countries, and Australia. ${ }^{37}$ Not only in his first year in office, 'Act East' policy has continued to be Modi's wellknown style of engaging with other countries in the following years. Hindustan Times wrote that the 'Act East' policy has set a new benchmark of diplomacy, marking a new and more active foreign policy of India. ${ }^{38}$

Figure 1. Modi's Frequent Foreign Trips

Source:

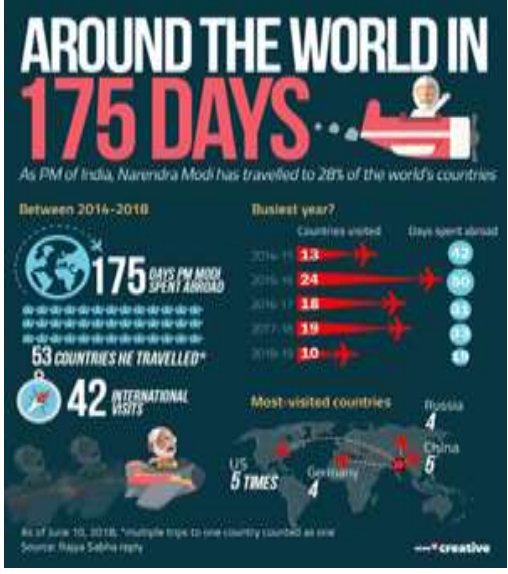

https://www.news18.com/photogallery/india/jul y-2018-best-infographics-of-the-month1798549-13.html

Not only in cooperation and diplomacy, Modi also put concern on building up India's military power. During Modi's four-year administration, India has showed its commitment to build up its military through increased military budget. In 2017, India broke into top 5 defence

\footnotetext{
${ }^{37}$ D. Rajendram (2014). India's new Asia-Pacific strategy: Modi acts East. Sydney: Lowly Institute for International Policy.

${ }^{38}$ S. Singh (2018, January 29). India-ASEAN Summit: Modi's Act East Policy has set new benchmark. Retrieved December 12, 2018, from Hindustan Times:

https://www.hindustantimes.com/opinion/indiaasean-summit-modi-s-act-east-policy-has-set-newbenchmarks/storyhK24IToZ6F5SMqRCaTsrPI.html
} 
Peter Sean Lie, Anak Agung Banyu Perwita | The Modi Factor: The Role Of Narendra

Modi's Idiosyncratic Factors In India's

Foreign Policy Responses Towards China

Pakistan Economic Corridor

spender globally, with US $\$ 52.5$ billion spent on military, according to 'Military Balance 2018' report. ${ }^{39}$ In result, India in 2018 is ranked $3^{\text {rd }}$ in terms of largest military in the world, and with huge military budget, the prospect of improvement in military is still apparent. ${ }^{40}$

\section{Figure 2. Top 5 Global Defence Spender (in billion US\$)}

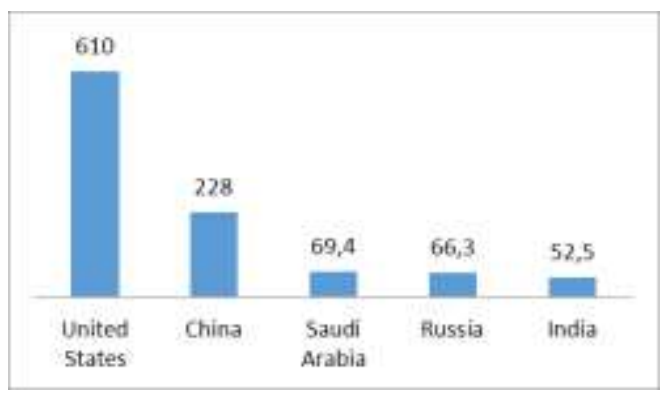

\section{Source:}

https://www.iiss.org/publications/themilitary-balance/the-military-balance-2018

Through 'Make in India' policy in the defence sector, India has achieved some milestones by opening up 100\% Foreign Direct Investment in defence sector, promoting exports, providing fiscal incentives, and increased investment in defence $\mathrm{RnD}$ sector, according to Defence Manufacturing Sector Achievement Report. ${ }^{41}$ Defence industrial complex is also something that India is concerned

\footnotetext{
${ }^{39}$ International Institute for Strategic Studies. (2018, February). The Military Balance 2018. Retrieved December 12, 2018, from International Institute for Strategic Studies: https://www.iiss.org/publications/the-militarybalance/the-military-balance-2018

${ }^{40}$ Tramballi, \& Missaglia, (2018). India: The Modi Factor. Milan: ISPI.

${ }^{41}$ Make in India. (2017, February 13). Defence Manufacturing Sector Achievement Report.

Retrieved December 12, 2018, from Make in India Official Website: https://drive.google.com/file/d/0BTv7_upCKANRmtia05TUWsxRms/view
}

about. In DefExpo2018, Modi said that although India is a peaceful country, the government could not deny its responsibility to protect its citizens through "equipping India's armed forces through the establishment of a strategically independent defence industrial complex." 42 Under Modi's administration, India has also been engaging with defence diplomacy. According to Gregory Winger, a Professor at University of Cincinnati, defence diplomacy is an effort to engage with other countries through military cooperation to pursue a strategic and geopolitical purpose. ${ }^{43}$ In a span of two years only, the Indian government under Modi has signed MOUs of defence cooperation with more than 20 countries, according to Indian Ministry of Defence official document. ${ }^{44}$

When it comes to security and territorial integrity, India is not hesitant to "show muscle" and being assertive in using its military. ${ }^{45}$ The world has seen India's

\footnotetext{
${ }^{42}$ Roche, E. (2018, April 13). DefExpo 2018: Govt to boost defence manufacturing, says Narendra Modi. Retrieved December 12, 2018, from LiveMint: https://www.livemint.com/Politics/fHWAjbK4BSm koEgfukiuRL/Narendra-Modi-at-Defence-ExpoGovts-commitment-is-to-peace.html ${ }^{43}$ G. Winger (2014). The Velvet Gauntlet: a Theory of Defense Diplomacy. Retrieved December 16, 2018, from Institute for Human Sciences: http://www.iwm.at/publications/5-junior-visitingfellows-conferences/vol-xxxiii/the-velvet-gauntlet/

${ }^{44}$ Indian Ministry of Defence. (2016). Transforming India: Key Accomplishments in the Defence SEctor under the Narendra Modi Government. Retrieved December 12, 2018, from Indian Ministry of Defence: https://mod.gov.in/sites/default/files/accomplishmen ts.pdf

${ }^{45}$ R. Singh (2018, May 26). Four years of Modi govt: India showed will and muscle, but funds crunch dulls defence shine. Retrieved December 12, 2018, from Hindustan Times: https://www.hindustantimes.com/india-news/four-
} 
Peter Sean Lie, Anak Agung Banyu Perwita | The Modi Factor: The Role Of Narendra

Modi's Idiosyncratic Factors In India's

Foreign Policy Responses Towards China

Pakistan Economic Corridor

military power being deployed when security and border terrorism issue rose in India and Pakistan borders. In the wake of terrorist attack to Indian Army base in Uri on September 18, 2016, India launched a series of surgical attacks in Pakistan occupied Kashmir (PoK) in less than two weeks later. Indian Army Director General of Military Operation, Ranbir Singh in his statement said that the growing terrorist activities in the Line of Control in Jammu and Kashmir "has been a matter of serious concern." 46 Modi even stated that the surgical strike "was a proof to the world about India's strengh." ${ }^{\text {N7 }}$ NDTV even boldly stated that Modi utilizes military power to speak on its behalf and to show Indian government stance on several crucial issues. $^{48}$

\section{Implication of CPEC to Sino-Indian Relations}

As part of the BRI, the ChinaPakistan Economic Corridor (CPEC) is

years-of-modi-govt-india-showed-will-and-musclebut-funds-crunch-dulls-defence-shine/story-

VhdxTVg4i3pWkbCl788gsK.html

${ }^{46}$ ET Online. (2018, November 6). DGMO's text on "surgical strikes"on terrorist launch pads across LoC. Retrieved from Economic Times:

https://economictimes.indiatimes.com/news/defence /dgmos-text-on-surgical-strikes-on-terrorist-launchpads-across-

loc/articleshow/54582133.cms?from=mdr

${ }^{47}$ Indo Asian News Service. (2017, August 15).

Surgical strike proved India's strength, says PM

Modi. Retrieved December 13, 2018, from

Hindustan Times:

https://www.hindustantimes.com/india-

news/surgical-strike-proved-india-s-strength-sayspm-modi/story-

qPAYDkmyGRByG1RSfyeowJ.html

${ }^{48}$ M. S. Aiyar (2018, March 4). Modi Government Uses Army To Speak On Its Behalf. Retrieved December 12, 2018, from NDTV:

https://www.ndtv.com/opinion/modi-governmentuses-army-to-speak-on-its-behalf-by-mani-shankaraiyar-1819086

considered one of the flagship projects that impose great importance for the development of BRI. Dr. Bilal Ahmed, Director of Research and Development at the Federation of Pakistan Chambers of Commerce \& Industry claimed that CPEC is the "central organ of BRI." Not only being important to the the BRI, the CPEC also marks a huge milestone of SinoPakistan relations. Former Prime Minister of Pakistan, Shahid Khaqan Abbasi praised the project, saying that Sino-Pakistan relationship "has attained new heights after the China-Pakistan Economic Corridor that is a game changer for the region and beyond." 49 The CPEC is formalized in April 2015 through 51 MoUs signed during Xi's visit to Islamabad. ${ }^{50}$ Moving beyond the bilateral relationship between the two countries, the CPEC is predicted to be beneficial to the region of South Asia as a whole, as it will enhance connectivity in the region. ${ }^{51}$ According to the official website, CPEC put emphasis on "improving the lives of people of Pakistan and China by building an economic corridor promoting bilateral connectivity, construction, explore potential bilateral investment, economic and trade, logistics and people to people contact for regional connectivity." 52

\footnotetext{
${ }^{49}$ Shahid Abbasi (2017). Pakistan Prime Minister Official Message on China Pakistan Economic Corridor. Retrieved from China Pakistan Economic Corridor Website:

http://www.cpec.gov.pk/messages/1

${ }^{50}$ I. Haider (2015, April 20). Details of agreements signed during Xi's visit to Pakistan. Retrieved from Dawn: https://www.dawn.com/news/1177129

${ }^{51}$ Government of Pakistan. (2017, November 21).

Long Term Plan for China-Pakistan Economic

Corridor (2017-2030). Retrieved from China

Pakistan Economic Corridor Official Website: https://www.pc.gov.pk/uploads/cpec/LTP.pdf ${ }^{52}$ CPEC Project Director. (2018). CPEC Vision \& Mission. Retrieved from China Pakistan Economic Corridor: http://cpec.gov.pk/vision-mission/3
} 
Peter Sean Lie, Anak Agung Banyu Perwita | The Modi Factor: The Role Of Narendra

Modi's Idiosyncratic Factors In India's

Foreign Policy Responses Towards China

Pakistan Economic Corridor

CPEC route runs across the area of Kashmir, the government of India fully opposes the project. Despite opposition from India, China still hopes that India would participate on the project. This is expressed through many occasions, for instance when Chinese Ambassador to India Luo Zhaohui made a statement to call India to join the project, saying that the BRI would give both countries with "fresh opportunities and highlights for the bilateral cooperation.",53

China ultimately invited India to the 2017 Belt and Road Forum for International Cooperation held in May 2017, which was the main multilateral stage for Beijing to promote the BRI. According to an official statement from MEA, India got Beijing's invitation to take part in the Belt and Road Forum. More than 100 countries participated in the Forum, sending their representatives and head of states to Beijing for a celebration of "the project of the century." 54 Even countries like the US, Japan, and South Korea, who are known for having a quite bitter relationship with China, sent representatives to participate in the Forum. ${ }^{55}$ India on the other hand, did not

\footnotetext{
${ }^{53}$ Zhaohui, L. (2017, Juni 8). Remarks by H.E. Ambassador Luo Zhaohui at the United Service Institution of India. Retrieved from Chinese Embassy Website:

http://in.chineseembassy.org/eng/gdxw/t1459430.ht $\mathrm{m}$

${ }^{54}$ Indian Ministry of External Affairs. (2017, May 13). Official Spokeperson's response to a query on participation of India in OBOR/BRI Forum.

Retrieved from Ministry of External Affairs India: https://mea.gov.in/mediabriefings.htm?dtl/28463/Official+Spokespersons+re sponse+to

${ }^{55}$ S. Patranobis (2017, May 17). India absent at Belt and Road Forum but its presence felt at China's mega show. Retrieved December 27, 2018, from Hindustan Times:

https://www.hindustantimes.com/world-news/india-
}

even send any representative to the Forum, "boycotting" the Forum, said East Asia Forum. $^{56}$ In response to the invitation, official spokesperson from MEA made a statement, saying that:

"We are of firm belief that connectivity initiatives must be based on universally recognized international norms, good governance, rule of law, openness, transparency and equality. Connectivity initiatives must follow principles of financial responsibility to avoid projects that would create unsustainable debt burden for communities; balanced ecological and environmental protection and preservation standards; transparent assessment of project costs; and skills and technology transfer to help long term running and maintenance of the assets created by local communities. Connectivity projects must be pursued in a manner that respects sovereignty and territorial integrity. No country can accept a project that ignores its core concerns on sovereignty and territorial integrity ".57

India's opposition to the Project is rooted in its concern on sovereignty and territorial integrity of its disputed territory with Pakistan, which is Kashmir. Since India and Pakistan's independence in 1947, they have started to dispute the area. ${ }^{58}$ India's stance on Kashmir has never been

the-elephant-at-china-s-grand-belt-and-roadforum/story-LED5b2tXRFBF6XpVSiG5gL.html

${ }^{56}$ Park \& Singh (2017, June 13). Why India boycotted the Belt and Road Forum. Retrieved December 27, 2018, from East Asia Forum: http://www.eastasiaforum.org/2017/06/13/whyindia-boycotted-the-belt-and-road-forum/

${ }^{57}$ Indian Ministry of External Affairs. (2017, May 13). Official Spokeperson's response to a query on participation of India in OBOR/BRI Forum.

Retrieved from Ministry of External Affairs India: https://mea.gov.in/media-

briefings.htm?dtl/28463/Official+Spokespersons+re sponse+to

${ }^{58}$ CNN. (2018, March 25). Kashmir Fast Fact.

Retrieved from CNN:

https://edition.cnn.com/2013/11/08/world/kashmirfast-facts/index.html 
Peter Sean Lie, Anak Agung Banyu Perwita | The Modi Factor: The Role Of Narendra

Modi's Idiosyncratic Factors In India's

Foreign Policy Responses Towards China

Pakistan Economic Corridor

changed throughout the time. "The entire state of Jammu and Kashmir is an integral part of India, Pakistan is an illegal and forcible occupation of a part of the Indian state through aggression," according to a recent official statement from MEA. ${ }^{59}$ Even in Indian Ministry of Home Affairs, there is a division called Jammu \& Kashmir Division, which specifically functions as the governing body to administer all matters related to the State of Jammu and Kashmir, including "coordinating with Ministry of Defence as regards manning and managing the line of control between India and Pakistan. "60 India also took note on Pakistan's rationale on claiming the territory, which is to let the people have a referendum to choose between India and Pakistan. Ultimately, India argues that the referendum is not valid because Pakistan never comply with the preconditions of the referendum, as described in MEA official document about Jammu and Kashmir conflict:

"The government of Pakistan wrecked any possibility of plebiscite being conducted by not implementing part II of the resolution, perhaps because it was fully aware of what the result of such an exercise would be. The Pakistani troops, which were to withdraw from the state did not do so. As a result, normal conditions

\footnotetext{
${ }^{59}$ Indian Ministry of External Affairs. (2018, June 14). Official Spokesperson's response to a question on the Report by the Office of the High

Commissioner for Human Rights on "The human rights situation in Kashmir". Retrieved from Indian Ministry of External Affairs:

https://www.mea.gov.in/media-

briefings.htm?dtl/29978/Official_Spokespersons_res ponse_to_a_question_on_the_Report_by_the_Offic e_of_the_High_Commissioner_for_Human_Rights_ on_The_human_rights_situation_in_K

${ }^{60}$ Indian Ministry of Home Affairs. (2018, December 21). Jammu and Kashmir Division. Retrieved from Indian Ministry of Home Affairs: https://mha.gov.in/division_of_mha/jammukashmir-division
}

under which a plebiscite could be held were never created."

In short, India firmly believes in the notion that the whole state of Jammu and Kashmir is an integral part of India, even in Pakistan-occupied Kashmir. Other countries who recognize that Kashmir is Pakistan's territory, does not respect India's sovereignty and territorial integrity, according to India's perspective. In the case of CPEC, even though the government of China has said that it does not want to be involved in Kashmir dispute, China indirectly recognizes that Pakistanoccupied Kashmir is Pakistan's territory through the Corridor that runs through Pakistan-occupied Kashmir. ${ }^{62}$ This has made India perceives the Corridor as a violation of its sovereignty and territorial integrity.

As one of its core concerns, a violation of India's sovereignty would result in a more hostile India towards China. India's move to be completely absent from the Belt and Road Forum is seen as a disrespecting gesture towards China, seeing that the 2017 Belt and Road Forum is China's megaevent. ${ }^{63}$ Some analysts argued that India's "boycott" of the Belt and Road Forum has resulted to political tension, especially when China

\footnotetext{
${ }^{61}$ Indian Ministry of External Affairs. (2003, April 1). The Jammu and Kashmir Issue. Retrieved from Indian Ministry of External Affairs: https://mea.gov.in/in-focusarticle.htm?18971/The+Jammu+and+Kashmir+Issu e

${ }^{62}$ J. Naqvi (2017, May 9). China invites India to join One-Belt-One-Road project. Retrieved December 27, 2018, from Dawn: https://www.dawn.com/news/1331943

${ }^{63}$ P. Taneja (2017, May 15). Why India missed China's Belt and Road summit. Retrieved January 9, 2019, from The Interpreter: http://www.lowyinterpreter.org/the-interpreter/whyindia-missed-china-s-belt-and-road-summit
} 
stated that it has hardened its opposition on India entering the NSG. ${ }^{64}$

When Beijing urged India to formally support its "One-China" policy, India ultimately declined and asked Beijing to stop the CPEC instead. ${ }^{65}$ India even went further to invite a delegation from Taiwanese parliamentarians to India to increase its bargaining chip, an action that was termed "playing with fire" by Chinese government-run media Global Times. ${ }^{66}$ Although India has numerously communicated their concerns over the project, there is no substantial action from the Chinese side to address India's concerns. The Indian government is under the impression that China does not do much in addressing the violation of sovereignty by the Corridor, as the investment to the project continues. ${ }^{67}$

India also believes that China and Pakistan did not consult India before officially launched the project. In 2016 Raisina Dialogue, a multilateral platform of multi-sectoral discussion among world

\footnotetext{
${ }^{64}$ M. Singh (2019, December 3). India's Bid for the Nuclear Suppliers Group. Retrieved from Global Risk Insights:

https://globalriskinsights.com/2018/11/indias-bidnuclear-suppliers-group-nsg/

${ }^{65}$ D. R. Chaudhury (2018, June 7). Stop working in Pakistan-occupied Kashmir, says India after being urged to back 'One China'. Retrieved from The Economic Times: https://economictimes.indiatimes.com/news/defence /stop-work-in-pakistan-occupied-kashmir-saysindia-after-being-urged-to-back-onechina/articleshow/64500030.cms

${ }^{66}$ Y. Ning (2017, December 4). New Delhi will suffer losses if it plays Taiwan card. Retrieved from Global Times:

http://www.globaltimes.cn/content/1033001.shtml

${ }^{67}$ A. Bhaumik (2018, September 21). Beijing nudges Delhi to reaffirm One-China policy. Retrieved from Deccan Herald: https://www.deccanherald.com/national/beijingnudges-delhi-reaffirm-one-china-policy673697.html
}

leaders, businesses, media hosted by Indian MEA and Observer Research Foundation, Indian Minister of State for External Affairs Vijay Kumar Singh stated the importance of a connectivity projects to "follow a consultative process to be able to achieve a shared and integrated vision of connectivity. "68 Two years later in the same platform, Indian External Affairs Ministry Sushma Swaraj pointed out that it is essential for connectivity projects to go though "consultative process and also respect for sovereignty and territorial integrity." 69 This further deteriorates India's trust towards China, who does not consult India beforehand in this matter of connectivity project. Also, India and China communication mechanism mentioned earlier in this Chapter, is also in questions.

\section{India's Foreign Policy Responses towards CPEC}

India's firm opposition towards the BRI, and the Corridor in particular, is the very first policy response of India towards the CPEC project. India has been outspoken about this and it has utilized many canals to voice out their concerns, from Indian Ministry of External Affairs (MEA) official statements in the website to government officials' statement, including the Prime Minister himself. The form of

\footnotetext{
${ }^{68}$ Observer Research Foundation. (2016, November 6). Raisina Dialogue 2016 Conference Report. Retrieved from Orf Online: https://www.orfonline.org/wpcontent/uploads/2016/10/Raisina2016_Report.pdf ${ }^{69}$ S. Swaraj (2018, January 17). Address by External Affairs Minister at Third Raisina Dialogue, New Delhi (January 17, 2018). Retrieved from Observer Research Foundation: https://www.orfonline.org/wpcontent/uploads/2018/01/Sushma-SwarajSpeech.pdf
} 
Peter Sean Lie, Anak Agung Banyu Perwita | The Modi Factor: The Role Of Narendra

Modi's Idiosyncratic Factors In India's

Foreign Policy Responses Towards China

Pakistan Economic Corridor

opposition is also demonstrated by being absent at the Belt and Road Forum.

India's criticism on China's grand infrastructure masterpiece has been articulated since 2014, when the Indian government has just started noticing the infrastructure cooperation activity in Pakistan-occupied Kashmir. Indian External Affairs Minister Sushma Swaraj made a statement, saying:

"Government has seen reports with regard to China and Pakistan being involved in infrastructure building activities in Pakistan-Occupied Kashmir (PoK), including construction of the CPEC. Government has conveyed its concerns to China about their activities in PoK, and asked them to cease such activities."

The opposition continued at the first Raisina Dialogue on March 2016, a multilateral platform of multi-sectoral discussion among world leaders, businesses, and media, hosted by the Indian MEA and Observer Research Foundation. In the event, Minister Swaraj made clear that India sees the importance of connectivity in Asia, but she also implicitly criticizing the BRI without mentioning the project particularly. One year later in the same platform, Narendra Modi opened the Raisina Dialogue with his inaugural speech, implicitly criticizing the BRI project;

"We appreciate the compelling logic of regional connectivity for peace, progress, and prosperity. However, equally, connectivity in itself cannot override or undermine the sovereignty of other nations. Only by respecting the sovereignty of countries involved, can regional connectivity corridors fulfill their promise and avoid differences and discord."

In 2018 Raisina Dialogue, again Minister Sushma Swaraj voiced out her concerns on international connectivity projects. Minister Swaraj indirectly criticizing the BRI by saying that connectivity projects should go through a "consultative process and must be based on norms of transparency, good governance, commercial viability, fiscal responsibility and respect for sovereignty and territorial integrity." In her visit to China on April 2018, Minister Swaraj was firm on her stance when persuaded by China to support the BRI. Her opposition was in form of communique released in the visit, which is actually not only talking about the BRI issue.

From Indian MEA official documents, India has stated its firm opposition several times. In response to China's invitation to attend the Belt and Road Forum 2017, India has made clear that it could not accept "a project that ignores its core concerns on sovereignty and territorial integrity." With that being said, India made a full-fledge opposition by not sending even a single person to the Forum, which was not according to what Chinese foreign minister Wang Yi had expected. Wang Yi told the media that he believed India would send representative to the Forum, saying "although the Indian leader will not be here, India will have a representative. We welcome the Indian representative as well as members of business and finance community to take part of the event."

Indian MEA official website also responded to the fuss in the media about the possibility of India to eventually join BRI. NDTV reported that India should and will eventually join the BRI because of the vast economic benefits that New Delhi would gain. Responding to this, Indian MEA official website reassured once again that India will not compromise the Project, saying that "our position on OBOR/BRI is clear and there is no change." Narendra Modi himself also reaffirmed India's stance 
Peter Sean Lie, Anak Agung Banyu Perwita | The Modi Factor: The Role Of Narendra

Modi's Idiosyncratic Factors In India's

Foreign Policy Responses Towards China

Pakistan Economic Corridor

towards BRI and CPEC in the Shanghai Cooperation Organization (SCO) Summit on June 2018 in Qingdao. Despite being the only country in the members of SCO who oppose the BRI, Modi confidently addressed the importance for connectivity projects to respect sovereignty and territorial integrity.

In response to the ongoing construction activity of CPEC recently, India voiced out to urge China to stop the construction activity of CPEC in PoK. Indian Minister of State in External Affairs, Vijay Kumar Singh emphasized that the whole Jammu and Kashmir is part of India, and that the government of India is aware of the construction activities. Singh continued, saying that "We (India) has conveyed to the Chinese side, including at the highest level, our concern over these activities, which we see as violating our sovereignty and territorial integrity." These public statements done by various Indian government officials, including the Prime Minister, and also its absolute absence in the Belt and Road Forum, have again reaffirmed India's stance on the BRI project, particularly the CPEC that runs through PoK.

On the other hand, India also have an initiative to prevent a worse relationship with China by having Wuhan Informal Summit, which was conducted on April 2729, 2018. The purpose of the meeting, according to Indian MEA press release, is "to exchange views on overarching issues of bilateral and global importance, and to elaborate both countries' respective visions and priorities for national development in the context of the current and future international situation." With a relaxed and informal setting, Modi and Xi had to be in seven events over the two-day summit. According to the Summit Brief, four out of the seven meetings were one-to-one

between both leaders which means that Modi and $\mathrm{Xi}$ spent quite a lot of time together in a private setting.

Despite the sudden announcement, the Wuhan Summit has already proposed by Modi in the sideline meeting of Shanghai Cooperation Organization (SCO). According to China's Ambassador to India Luo Zhaohui, the initiative of having an informal summit came from Modi when the two leaders held bilateral talks at the sideline of SCO Summit. This means that the informal summit was initiated in the heated issue of India's opposition to BRI, or after India refused to send representatives to Belt and Road Forum in May 2017, even before the Doklam standoff happened.

Even though there are no MOU or agreement made, the Summit has successfully covered important bilateral, regional, and international issues. Some of the important talking points are: Strengthening strategic communication, border management and territory issues, economic cooperation, and cultural \& people-to-people exchange.

Due to its sudden announcement, the media has said that the Summit is deemed as "bold" diplomatic move, seeing that the situation between India and China was at its worst in years. Some media analyzed that the Summit is intended to fix the relationship between the two, as it is evident that the discussion also touched some of the most pressing problems that the two countries experienced, namely the CPEC issue and Doklam standoff. Brookings has labeled Wuhan Summit "an important signal of intent by India and China." Indian ambassador to China Gautam Bambawale told NDTV that with a long private time for Modi and Xi to talk, the Summit has been successful in giving 
Peter Sean Lie, Anak Agung Banyu Perwita | The Modi Factor: The Role Of Narendra

Modi's Idiosyncratic Factors In India's

Foreign Policy Responses Towards China

Pakistan Economic Corridor

clarity on some misconceptions of both countries.

\section{Role of Modi's Idiosyncratic Factors in India's Foreign Policy Responses towards CPEC}

As evident from the previous explanation on Modi's perception, he believes that CPEC should be opposed because it violates India's sovereignty and territorial integrity. Based on this perception, and seeing Modi's personal traits as an outspoken and firm in opposing to things that he perceive wrong, this explains how Modi's idiosyncratic factors correlates with the policy response to firmly oppose the CPEC. Modi once led a protest against a teacher who smoked in school, as he believed that teachers are supposed to show good examples to the students. When he was Chief Minister of Gujarat, he walked out of a TV interview because the interviewer did not respect his decision to not to talk about specific topic, and while he left the interviewer he said, "I hope we can continue to remain friends, I'll be happy". The people of Gujarat, years after Modi is no longer Chief Minister, admitted that they missed a strong leader like Modi, as reported by Mint. As Prime Minister, he has made some firm decisions, such as in Doklam when he kept his stance firm to block Chinese military from the Butanese territory. Modi in his speech at the stone-laying ceremony of "India International Conventionand Expo Centre" reaffirmed his commitment to make the government "tough and firm in taking decisions."

Modi's choice to give firm opposition to the project that he deemed wrong also correlates with his personal trait, which is outspoken and firm in opposing wrongdoings. India's full-fledge opposition stance by not sending any representative to the Belt and Road Forum reflects Modi's "brutish style of dealing with adversaries and rebels," as described by Mukhopadhyay, Narendra Modi's biographer.

Modi's main ideology, which is nationalist, has also contributed in influencing the decision to be firm to CPEC, which attempts to defend India's core concerns. His love of his country, added with his Hindu origins, made him a proud Hindu nationalist and he does not hesitate to admit that. During his interview with Reuters, Modi said that, 'I'm nationalist. I'm patriotic. Nothing is wrong. I'm a born Hindu. Nothing is wrong. So, I'm a Hindu nationalist." In this case, a person consider him or herself as Hindu nationalist or Hindutva is someone who believe that India is both a fatherland and a holy land, and whoever dare to disturb the peace and tranquillity of India should be handled with aggression. The implication of Hindutva to foreign policy is a more muscular and aggressive stance, unwillingness to compromise, and the use of force. In short, Modi's firm and outspoken personality, explain how India numerously stated its stance opposition towards China's CPEC project. His strong belief in nationalism implies that he would defend India's core concerns, in this case sovereignty, as the first priority.

On the other hand, fixing the relationship with China is important for Modi, because as have been discussed before, Modi considered China as both a great country and valuable economic partner. When Modi was Chief Minister, he visited China four times. In his 2011 visit, Modi was welcomed at the Great Hall of People, which according to protocol is to welcome foreign head of states or head of goverment, according to Narendra Modi Official Website. This means that Modi's 
visits have profound emotional impact towards China and he is highly respected in China. Modi has invested in his relationship in China since even before he was Prime Minister, and it has bear fruits of respect and deep relationship that Modi has towards China. This explained why Modi wants to fix the relationship with China, because India could not risk losing China as valuable economic partner.

Modi's foreign policy orientation also explains his decision to visit China and held the Wuhan Informal Summit. As discussed in Chapter II, Modi has introduced a more proactive foreign policy, marked with his 'Neighborhood First' and 'Act East' policies. Based on Indian MEA official document, 'Neighborhood First' policy has always been India's foreign policy foundation, seeing that the stability of neighbors can directly impact India. Seeing that India shares a 2,100 miles of border with China, New Delhi must be concerned of the stability of the two countries' relations. The Wuhan Informal Summit was seen as unecessary by some people because the two leaders were scheduled to meet again two months later, in the SCO Summit on June 2018, and three months later in Johannesburg's BRICS Summit. However, seeing that India should prioritize its neighbors under Modi's foreign policy, mending the relationship is seen as necessary. Mending relations with China by an informal summit in the midst of worsening relationship is seen as a normal thing to do, seeing that China is one of India's most significant neighbors.

We can also see footprints of Modi's charisma and personal touch style of relation-building in the Wuhan Informal Summit. As discussed in Chapter II, Modi has developed an extraordinary charisma in personal relationship. With his humble origin and down-to-earth image, he can make everybody at ease and feel close emotional connection. Modi's biographer Mukhopadhyay described Modi's down-toearth charisma with high praises,

"as I walked into his office, he made me forget that I had come to meet the chief minister of a significant state and that he was a political leader of considerable eminence., $" 70$ Robert Kaplan wrote in the Atlantic, "I have met Jimmy Carter, Bill Clinton, and both Bushes. At close range, Modi beats them all in charisma. ",71

His charisma in personal relationship is also supported by his rhetoric skills, which has been developed since young age, according to Dr. Bindeshawr Pathak, Modi's biographer. ${ }^{72}$

Modi's charisma in personal relationship and his long-acquaintance with China has been utilized by India to have Wuhan Informal Summit, which is branded as 'Modi's Personal Diplomacy.' In this case, Wuhan Summit is seen as a succesful diplomatic move because it combined the element of Modi's charisma, years of heartto-heart interactions with Chinese government when he was Chief Minister of Gujarat, and his personal relationship with Xi Jinping. ${ }^{73}$ Modi has been invested in building personal relations with Xi Jinping prior to the Informal Summit. Just a few days after being the Prime Minister,

\footnotetext{
${ }^{70}$ N. Mukhopadhyay (2013). Narendra Modi: The Man, the Times. New Delhi: Tranquebar Press.

${ }^{71}$ R. Kaplan(2009, April). India's New Face. Retrieved December 13, 2018, from The Atlantic: https://www.theatlantic.com/magazine/archive/2009 /04/indias-new-face/307332/

${ }^{72}$ B. Pathak (2017). The Making of a Legend: Narendra Damodardas Modi. New Delhi: Sulab International Center for Action Sociology.

73 A. Singh (2018, April 30). Modi-Jinping meet: The art of personal diplomacy. Retrieved January 14, 2019, from Governance Now: https://www.governancenow.com/views/columns/m odijinping-meet-the-art-of-personal-diplomacy
} 
Narendra Modi quickly invited Xi Jinping to visit Gujarat, Modi's home state. This visit is special for Xi Jinping because he is the first Chinese leader after 60 years to receive public welcome. ${ }^{74}$ When Modi visited China, he chose to stop by at Xi'an in Shaanxi province, rather than Beijing. Some believes that this is Modi's warm diplomatic gesture towards China and specifically towards Xi Jinping, seeing that $\mathrm{Xi}$ 'an is Xi Jinping's hometown. ${ }^{75}$ Modi's visit to Xi'an is special because Xi Jinping himself went to Xi'an to welcome him in person, marking Xi's first time welcoming foreign leader outside Beijing. "This is the first time I have welcomed a foreign leader to my hometown and I hope you have a happy stay, "Xi said, quoted by Xinhua. ${ }^{76}$

This shows how invested Modi in building relationship with $\mathrm{Xi}$ Jinping. Seeing that there is no MoU or agreement signed, the format of Wuhan Summit was designed for the two leaders to talk in an informal setting. ${ }^{77}$ The way Wuhan

\footnotetext{
${ }^{74}$ Times News Network. (2014, September 18). Chinese President Xi Jinping's India visit: After six decades, a Chinese leader gets public welcome. Retrieved January 14, 2019, from The Times of India:

https://timesofindia.indiatimes.com/india/ChinesePresident-Xi-Jinpings-India-visit-After-six-decadesa-Chinese-leader-gets-public-

welcome/articleshow/42741311.cms

${ }^{75}$ S. Tiezzi (2015, May 15). Modi's First Stop in China: Why Xi'an? Retrieved January 14, 2019, from The Diplomat:

https://thediplomat.com/2015/05/modis-first-stopin-china-why-xian/

${ }^{76}$ Xinhua. (2015, May 15). Hometown Diplomacy highlights Modi's Xi'an Tour. Retrieved January 14, 2019, from Xinhua:

http://www.xinhuanet.com/english/201505/15/c_134239928.htm

${ }^{77}$ Kumar\& Singh (2018, May 24). Wuhan Summit Issue Brief. Retrieved from Indian Council of World Affairs:
}

Informal Summit was designed and implemented suggests that the Summit was made to accomodate Modi's strength in charisma and personal diplomacy. As the head of government of India, it is also Modi's privilege to be the frontline of diplomacy when it comes to important summits with foreign leaders, according to protocol. $^{78}$

Indian policy response towards China's CPEC Project ultimately reflects Modi's foreign policy foundation, which is the balance of shanti (peace) and shakti (power) in executing foreign policy. Modi has stated that he envisioned to have " $a$ grand design for achieving India's century through a balance between the high road of peace and a non-nonsense toughness towards threats to national security."79 Modi's opposition towards the CPEC has shown India's toughness and power in being firm on core concerns. While Modi's initiative to have Wuhan Informal Summit with China to fix the worsening relations between the two is the form of pursuing peace, not only with China but also in the region.

\section{Conclusion}

The combination of Modi's perception towards CPEC and China and his personal traits has correlated a strong opposition towards the CPEC, and an

\footnotetext{
https://icwa.in/pdfs/IB/2014/WuhanSummitIB24052 018.pdf

${ }^{78}$ Indian Ministry of External Affairs. (2014, April

4). Protocol and Diplomacy: Blending style with substance. Retrieved January 15, 2019, from Indian Ministry of External Affairs:

https://www.mea.gov.in/in-focusarticle.htm?23169/Protocol+and+Diplomacy+Blend ing+style+with+substance

${ }^{79}$ Indo Asian News Service. (2013, October 18).

Build foreign policy on culture, economy, security:

Modi. Retrieved December 12, 2018, from https://news.yahoo.com/build-foreign-policyculture-economy-security-modi-152803353.html
} 
Peter Sean Lie, Anak Agung Banyu Perwita | The Modi Factor: The Role Of Narendra Modi's Idiosyncratic Factors In India's Foreign Policy Responses Towards China Pakistan Economic Corridor

attempt to fix Sino-Indian worsening relationship through Wuhan Informal Summit. Modi also fulfills 7 out of 8 conditions in which a leader's would be likely to correlate with foreign policy, which means that Modi's idiosyncratic factors have considerable correlation to India's foreign policy responses towards China's CPEC. His personal traits suggest a strong, tough, and outspoken leader, which explains his decision to firmly oppose the CPEC, while his pursue of peace and exceptional charisma in personal diplomacy explains India's decision to fix the worsening Sino-Indian relations through Wuhan Informal Summit. Modi also prefers to deal with foreign affairs with his principle of balancing shanti (peace) and shakti (power), which explains the toughness of India in opposing CPEC, and India's initiative to fix a worsening relations and pursue peace with China. 
Peter Sean Lie, Anak Agung Banyu Perwita | The Modi Factor: The Role Of Narendra Modi's Idiosyncratic Factors In India's Foreign Policy Responses Towards China Pakistan Economic Corridor

\section{REFERENCES}

Abbasi, S. K. (2017). Pakistan Prime Minister Official Message on China Pakistan Economic Corridor. Retrieved from China Pakistan Economic Corridor Website: http://www.cpec.gov.pk/messages/1

Aiyar, M. S. (2018, March 4). Modi Government Uses Army To Speak On Its Behalf. Retrieved December 12, 2018, from NDTV: https://www.ndtv.com/opinion/modigovernment-uses-army-to-speak-on-its-behalf-by-mani-shankar-aiyar-1819086

Baker McKenzie. (2017). Belt \& Road: the Prospects and Perils of Building China's New Silk Road. Baker McKenzie.

Bhaumik, A. (2018, September 21). Beijing nudges Delhi to reaffirm One-China policy. Retrieved from Deccan Herald: https://www.deccanherald.com/national/beijing-nudgesdelhi-reaffirm-one-china-policy-673697.html

BJP. (2017). Shri Narendra Modi. Retrieved December 4, 2018, from Bharatiya Janata Party: http://www.bjp.org/leadership/shri-narendra-modi

BJP. (2018). The Common Man who became the Prime Minister of India - Narendra Modi. Retrieved from Bharatiya Janata Party: http://www.bjp.org/leadership/shri-narendramodi

Chandrasekar, V. S., \& MacAskill, A. (2014, July 15). Narendra Modi, Xi Jinping pledge to resolve India-China border dispute. Retrieved from Livemint: https://www.livemint.com/Politics/7kuzKNe9PW3TND0AY13uYJ/Narendra-Modimeets-Chinese-president-Xi-Jinping-ahead-of-Br.html

Chatterjee, R. (2016, July 15). When Prime Minister Narendra Modi was a Young NCC Cadet. Retrieved December 3, 2018, from Huffington Post: https://www.huffingtonpost.in/2015/01/29/modi-ncc_n_6568430.html

Chaudhury, D. R. (2018, April 26). Modi's personal touch to diplomacy furthers Indian interests worldwide. Retrieved December 13, 2018, from The Economic Times: https://economictimes.indiatimes.com/news/politics-and-nation/modis-personal-touch-todiplomacy-furthers-indian-interests-worldwide/articleshow/63930507.cms

Chaudhury, D. R. (2018, June 7). Stop working in Pakistan-occupied Kashmir, says India after being urged to back 'One China'. Retrieved from The Economic Times: https://economictimes.indiatimes.com/news/defence/stop-work-in-pakistan-occupiedkashmir-says-india-after-being-urged-to-back-one-china/articleshow/64500030.cms

Cheong, D. (2018, January 10). China's foreign policy more proactive under Xi: Expert. Retrieved December 17, 2018, from The Straits Times: https://www.straitstimes.com/asia/east-asia/chinas-foreign-policy-more-proactive-underxi-expert

Chunying Hua. (2018, January 29). Foreign Ministry Spokesperson Hua Chunying's Regular Press Conference on January 29, 2018. Retrieved from Ministry of Foreign Affairs of the People's Republic of China: https://www.fmprc.gov.cn/mfa_eng/xwfw_665399/s2510_665401/t1529951.shtml

CNN. (2018, March 25). Kashmir Fast Fact. Retrieved from CNN: https://edition.cnn.com/2013/11/08/world/kashmir-fast-facts/index.html

CPEC Project Director. (2018). CPEC Vision \& Mission. Retrieved from China Pakistan Economic Corridor: http://cpec.gov.pk/vision-mission/3 
Peter Sean Lie, Anak Agung Banyu Perwita | The Modi Factor: The Role Of Narendra Modi's Idiosyncratic Factors In India's Foreign Policy Responses Towards China Pakistan Economic Corridor

Dasgupta, S. (2018, January 27). China should not ignore India's CPEC concerns: India Ambassador Gautam Bambawale. Retrieved from The Times of India: https://timesofindia.indiatimes.com/world/china/china-should-not-ignore-indias-cpecconcerns/articleshow/62667036.cms

ET Online. (2018, November 6). DGMO's text on "surgical strikes"on terrorist launch pads across $\quad$ LoC. Retrieved from Economic Times: https://economictimes.indiatimes.com/news/defence/dgmos-text-on-surgical-strikes-onterrorist-launch-pads-across-loc/articleshow/54582133.cms?from=mdr

Godbole, S. (2018, May 23). Wuhan Summit: An Important signal of intent by India and China. Retrieved from Brookings: https://www.brookings.edu/blog/upfront/2018/05/23/wuhan-summit-an-important-signal-of-intent-by-india-and-china/

Government of Pakistan. (2017, November 21). Long Term Plan for China-Pakistan Economic Corridor (2017-2030). Retrieved from China Pakistan Economic Corridor Official Website: https://www.pc.gov.pk/uploads/cpec/LTP.pdf

Haider, I. (2015, April 20). Details of agreements signed during Xi's visit to Pakistan. Retrieved from Dawn: https://www.dawn.com/news/1177129

Indian Ministry of Defence. (2016). Transforming India: Key Accomplishments in the Defence SEctor under the Narendra Modi Government. Retrieved December 12, 2018, from Indian Ministry of Defence: https://mod.gov.in/sites/default/files/accomplishments.pdf

Indian Ministry of External Affairs. (2003, April 1). The Jammu and Kashmir Issue. Retrieved from Indian Ministry of External Affairs: https://mea.gov.in/in-focusarticle.htm?18971/The+Jammu+and+Kashmir+Issue

Indian Ministry of External Affairs. (2014). Fast Track Diplomacy. Retrieved December 12, 2018, from Indian Ministry of External Affairs: https://www.mea.gov.in/Uploads/PublicationDocs/23979_MEA-Brochure-6thSep2014RE-LR.pdf

Indian Ministry of External Affairs. (2014, September 18). List of Documents signed during the State Visit of Chinese President Xi Jinping to India. Retrieved December 17, 2018, from Indian Ministry of External Affairs: https://www.mea.gov.in/bilateraldocuments.htm?dtl/24012/List+of+Documents+signed+during+the+State+Visit+of+Chi nese+President+Xi+Jinping+to+India

Indian Ministry of External Affairs. (2014, April 4). Protocol and Diplomacy: Blending style with substance. Retrieved January 15, 2019, from Indian Ministry of External Affairs: https://www.mea.gov.in/in-focus-

article.htm?23169/Protocol+and+Diplomacy+Blending+style+with+substance

Indian Ministry of External Affairs. (2015). Breakthrough Diplomacy. Retrieved December 12, 2018, from Indian Ministry of External Affairs: http://mea.gov.in/Images/pdf/Breakthroughdiplomacy.pdf

Indian Ministry of External Affairs. (2017, July 14). Challenges in India's Neighbourhood Policy. Retrieved January 14, 2019, from Indian Ministry of External Affairs: https://www.mea.gov.in/distinguished-lectures-detail.htm?674

Indian Ministry of External Affairs. (2017, May 13). Official Spokeperson's response to a query on participation of India in OBOR/BRI Forum. Retrieved from Ministry of 
Peter Sean Lie, Anak Agung Banyu Perwita | The Modi Factor: The Role Of Narendra Modi's Idiosyncratic Factors In India's Foreign Policy Responses Towards China Pakistan Economic Corridor

External Affairs India: https://mea.gov.in/mediabriefings.htm?dtl/28463/Official+Spokespersons+response+to

Indian Ministry of External Affairs. (2018, April 28). India-China Informal Summit at Wuhan. Retrieved from Indian Ministry of External Affairs: https://mea.gov.in/pressreleases.htm?dtl/29853/IndiaChina_Informal_Summit_at_Wuhan

Indian Ministry of External Affairs. (2018, June 14). Official Spokesperson's response to a question on the Report by the Office of the High Commissioner for Human Rights on "The human rights situation in Kashmir". Retrieved from Indian Ministry of External Affairs:

https://www.mea.gov.in/mediabriefings.htm?dtl/29978/Official_Spokespersons_response_to_a_question_on_the_Repor t_by_the_Office_of_the_High_Commissioner_for_Human_Rights_on_The_human_right s_situation_in_K

Indian Ministry of External Affairs. (2018, April 5). Official Spokesperson's response to a query on media reports regarding possible cooperation with China on OBOR/BRI. Retrieved from Indian Ministry of External Affairs: https://www.mea.gov.in/mediabriefings.htm?dtl/29768/Official+Spokespersons+response+to+a+query+on+media+repo rts+regarding+possible+cooperation+with+China+on+OBORBRI

Indian Ministry of Home Affairs. (2018, December 21). Jammu and Kashmir Division. Retrieved from Indian Ministry of Home Affairs: https://mha.gov.in/division_of_mha/jammu-kashmir-division

Indo Asian News Service. (2013, October 18). Build foreign policy on culture, economy, security: Modi. Retrieved December 12, 2018, from https://news.yahoo.com/buildforeign-policy-culture-economy-security-modi-152803353.html

Indo Asian News Service. (2017, August 15). Surgical strike proved India's strength, says PM Modi. Retrieved December 13, 2018, from Hindustan Times: https://www.hindustantimes.com/india-news/surgical-strike-proved-india-s-strengthsays-pm-modi/story-qPAYDkmyGRByG1RSfyeowJ.html

International Institute for Strategic Studies. (2018, February). The Military Balance 2018. Retrieved December 12, 2018, from International Institute for Strategic Studies: https://www.iiss.org/publications/the-military-balance/the-military-balance-2018

Jha, P. (2018, November 22). India working to 'recalibrate' ties with China, but will not sign on to Belt and Road Initiative. Retrieved from Hindustan Times: https://www.hindustantimes.com/india-news/india-working-to-recalibrate-ties-withchina-but-will-not-sign-on-to-belt-and-road-initiative/storyiTunr71mCRbXkVvHcxo29K.html

Kaplan, R. D. (2009, April). India's New Face. Retrieved December 13, 2018, from The Atlantic: https://www.theatlantic.com/magazine/archive/2009/04/indias-newface/307332/

Krishnan, A. (2018, April 23). Modi - Xi Meet: Rewards and Risks in PM's 'bold' diplomatic move. Retrieved from India Today: https://www.indiatoday.in/world/story/wuhansummit-rewards-and-risks-in-modi-s-bold-diplomatic-move-1217933-2018-04-23

Kugelman, M. (2018, February 18). Why India-China ties are under strain. Retrieved from Arab News: http://www.arabnews.com/node/1249021

Kumar, S., \& Singh, P. R. (2018, May 24). Wuhan Summit Issue Brief. Retrieved from Indian Council of World Affairs: https://icwa.in/pdfs/IB/2014/WuhanSummitIB24052018.pdf 
Peter Sean Lie, Anak Agung Banyu Perwita | The Modi Factor: The Role Of Narendra

Modi's Idiosyncratic Factors In India's

Foreign Policy Responses Towards China

Pakistan Economic Corridor

Lidarev, I. (2018, January 4). 2017: A Tough Year for China-India Relations. Retrieved from The Diplomat: https://thediplomat.com/2018/01/2017-a-tough-year-for-china-indiarelations/

Make in India. (2017, February 13). Defence Manufacturing Sector Achievement Report. Retrieved December 12, 2018, from Make in India Official Website: https://drive.google.com/file/d/0B-Tv7_upCKANRmtia05TUWsxRms/view

Modi, N. (2013, July 12). Interview with BJP leader Narendra Modi. (R. Colvin, \& S. Gottipati, Interviewers)

Modi, N. (2014, November 12). Opening Statement by Prime Minister at the 12th IndiaASEAN Summit. Retrieved December 12, 2018, from Indian Ministry of External Affairs: http://www.mea.gov.in/incoming-visitdetail.

Modi, N. (2017, January 17). Inaugural Address by Prime Minister at Second Raisina Dialogue, New Delhi. Retrieved from Indian Ministry of External Affairs: https://mea.gov.in/Speeches-

Statements.htm?dtl/27948/Inaugural_Address_by_Prime_Minister_at_Second_Raisina_ Dialogue_New_Delhi_January_17_2017

Modi, N. (2019, January 4). PM lays foundation stone for India International Convention and Expo Centre. Retrieved from Narendra Modi Official Website: https://www.narendramodi.in/pm-modi-lays-foundation-stone-of-india-internationalconvention-and-expo-centre-dwarka--541530

Mukhopadhyay, N. (2013). Narendra Modi: The Man, the Times. New Delhi: Tranquebar Press.

Nag, A. (2018, January 23). In Davos Debut, PM Modi Seeks Bigger Global Role For India. Retrieved December 13, 2018, from NDTV: https://www.ndtv.com/india-news/davos2018-pm-narendra-modi-seeks-bigger-global-role-for-india-1803573

Naqvi, J. (2017, May 9). China invites India to join One-Belt-One-Road project. Retrieved December 27, 2018, from Dawn: https://www.dawn.com/news/1331943

Narendra Modi Official Website. (2011, November 13). Gujarat Chief Minister Mr. Narendra Modi's Historic Visit to the People's Republic of China. Retrieved December 12, 2018, from Narendra Modi Official Website: https://www.narendramodi.in/gujaratchief-minister-mr-narendra-modi\%E2\%80\%99s-historic-visit-to-thepeople\%E2\%80\%99s-republic-of-china-4188

Observer Research Foundation. (2016, November 6). Raisina Dialogue 2016 Conference Report. Retrieved from Orf Online: https://www.orfonline.org/wpcontent/uploads/2016/10/Raisina2016_Report.pdf

Parameswaran, P. (2015, July 21). A New 'Proactive' Indian Foreign Policy under Modi? Retrieved from The Diplomat: https://thediplomat.com/2015/07/is-india-advancing-anew-proactive-foreign-policy-under-modi/

Park, S., \& Singh, R. (2017, June 13). Why India boycotted the Belt and Road Forum. Retrieved December 27, 2018, from East Asia Forum: http://www.eastasiaforum.org/2017/06/13/why-india-boycotted-the-belt-and-road-forum/

Pathak, B. (2017). The Making of a Legend: Narendra Damodardas Modi. New Delhi: Sulab International Center for Action Sociology.

Patranobis, S. (2017, May 17). India absent at Belt and Road Forum but its presence felt at China's mega show. Retrieved December 27, 2018, from Hindustan Times: 
Peter Sean Lie, Anak Agung Banyu Perwita | The Modi Factor: The Role Of Narendra Modi's Idiosyncratic Factors In India's Foreign Policy Responses Towards China Pakistan Economic Corridor

https://www.hindustantimes.com/world-news/india-the-elephant-at-china-s-grand-beltand-road-forum/story-LED5b2tXRFBF6XpVSiG5gL.html

Pethiyagoda, K. (2017, October 13). China-India relations: Millennia of peaceful coexistence meet modern day geopolitical interests. Retrieved from Brookings: https://www.brookings.edu/blog/order-from-chaos/2017/10/13/china-india-relationsmillennia-of-peaceful-coexistence-meet-modern-day-geopolitical-interests/

Press Trust India. (2014, December 14). Pakistan to go ahead with all projects in Pakistan Occupied Kashmir with China'. Retrieved from Economic TimesPro.

Press Trust of India. (2017, August 29). Doklam standoff: Thanks to PM Modi we've won battle without engaging in war, says Keshav Maurya. Retrieved January 14, 2019, from The Indian Express: https://indianexpress.com/article/india/doklam-standoff-thanks-topm-modi-weve-won-battle-without-engaging-in-war-says-keshav-prasad-maurya4819708/

Press Trust of India. (2018, August 9). India has asked China to stop construction in PoK: Government . Retrieved from The Economic Times: https://economictimes.indiatimes.com/news/politics-and-nation/india-has-asked-chinato-stop-construction-in-pok-government/articleshow/65341824.cms

Press Trust of India. (2018, April 27). Narendra Modi, Xi Jinping hold talks during informal Wuhan meeting. Retrieved from Livemint: https://www.livemint.com/Politics/6oEdw2MN9UkkKyP1PBiU7O/Narendra-Modi-XiJinping-hold-talks-during-informal-Wuhan-m.html

Press Trust of India. (2018, November 16). PM Modi, Xi Jinping Meet Removed "Misconceptions", Says Indian Envoy. Retrieved January 14, 2019, from NDTV: https://www.ndtv.com/india-news/pm-modi-xi-jinping-meet-removed-misconceptionssays-indian-envoy-1948466

Press Trust of India. (2018, September 20). Those who oppose BRI, CPEC will never succeed: Xi to Pakistan Army Chief. Retrieved January 7, 2019, from The Times of India: https://timesofindia.indiatimes.com/world/china/those-who-oppose-bri-cpec-willnever-succeed-xi-to-bajwa/articleshow/65887915.cms

Rajendram, D. (2014). India's new Asia-Pacific strategy: Modi acts East. Sydney: Lowly Institute for International Policy.

Roche, E. (2018, April 13). DefExpo 2018: Govt to boost defence manufacturing, says Narendra Modi. Retrieved December 12, 2018, from LiveMint: https://www.livemint.com/Politics/fHWAjbK4BSmkoEgfukiuRL/Narendra-Modi-atDefence-Expo-Govts-commitment-is-to-peace.html

Singh, A. (2018, April 30). Modi-Jinping meet: The art of personal diplomacy. Retrieved January 14, 2019, from Governance Now https://www.governancenow.com/views/columns/modijinping-meet-the-art-of-personaldiplomacy

Singh, K. (2018, March 8). Why China is winning in India's neighbourhood. Retrieved January 14, 2019, from https://www.livemint.com/Opinion/r2TI2ytdM70ec32Y1Q7DLO/Why-China-iswinning-in-Indias-neighbourhood.html 
Peter Sean Lie, Anak Agung Banyu Perwita | The Modi Factor: The Role Of Narendra

Modi's Idiosyncratic Factors In India's

Foreign Policy Responses Towards China

Pakistan Economic Corridor

Singh, M. (2019, December 3). India's Bid for the Nuclear Suppliers Group. Retrieved from Global Risk Insights: https://globalriskinsights.com/2018/11/indias-bid-nuclearsuppliers-group-nsg/

Singh, R. (2018, May 26). Four years of Modi govt: India showed will and muscle, but funds crunch dulls defence shine. Retrieved December 12, 2018, from Hindustan Times: https://www.hindustantimes.com/india-news/four-years-of-modi-govt-india-showedwill-and-muscle-but-funds-crunch-dulls-defence-shine/storyVhdxTVg4i3pWkbCl788gsK.html

Singh, S. (2018, January 29). India-ASEAN Summit: Modi's Act East Policy has set new benchmark. Retrieved December 12, 2018, from Hindustan Times: https://www.hindustantimes.com/opinion/india-asean-summit-modi-s-act-east-policyhas-set-new-benchmarks/story-hK24IToZ6F5SMqRCaTsrPI.html

Swaraj, S. (2018, January 17). Address by External Affairs Minister at Third Raisina Dialogue, New Delhi (January 17, 2018). Retrieved from Observer Research Foundation: https://www.orfonline.org/wp-content/uploads/2018/01/Sushma-SwarajSpeech.pdf

Taneja, P. (2017, May 15). Why India missed China's Belt and Road summit. Retrieved January 9, 2019, from The Interpreter: http://www.lowyinterpreter.org/theinterpreter/why-india-missed-china-s-belt-and-road-summit

The Economic Times. (2014, August 28). 5 Traits which make PM Narendra Modi stand out. Retrieved from The Economic Times: https://economictimes.indiatimes.com/slideshows/people/5-traits-which-make-pmnarendra-modi-stand-out/slideshow/41051339.cms

The Economic Times. (2018, September 17). Narendra Modi: Childhood Tales that Foretold the Coming of a Remarkable Leader. Retrieved December 3, 2018, from The Economic Times: https://economictimes.indiatimes.com/news/politics-and-nation/you-will-findpm-modi-in-the-life-of-child-narendra/articleshow/65839863.cms

The Economist. (2014, May 19). What Hindu nationalism means. Retrieved from The Economist: https://www.economist.com/the-economist-explains/2014/05/18/what-hindunationalism-means

The Times of India. (2014, September 5). Encourage students to think about naton, PM Narendra Modi tells teachers. Retrieved December 3, 2018, from The Times of India: https://timesofindia.indiatimes.com/india/Encourage-students-to-think-about-nation-PMNarendra-Modi-tells-teachers/articleshow/41761096.cms

Tiezzi, S. (2015, May 15). Modi's First Stop in China: Why Xi'an? Retrieved January 14, 2019, from The Diplomat: https://thediplomat.com/2015/05/modis-first-stop-in-chinawhy-xian/

Times News Network. (2014, September 18). Chinese President Xi Jinping's India visit: After six decades, a Chinese leader gets public welcome. Retrieved January 14, 2019, from The Times of India: https://timesofindia.indiatimes.com/india/Chinese-PresidentXi-Jinpings-India-visit-After-six-decades-a-Chinese-leader-gets-publicwelcome/articleshow/42741311.cms

Times of India. (2018, April 28). Modi-Xi's Informal Summit ends: Key takeaways. Retrieved from The Times of India: https://timesofindia.indiatimes.com/india/modi-xis-informalsummit-ends-5-key-takeaways/articleshow/63950531.cms 
Peter Sean Lie, Anak Agung Banyu Perwita | The Modi Factor: The Role Of Narendra Modi's Idiosyncratic Factors In India's Foreign Policy Responses Towards China Pakistan Economic Corridor

Tramballi, U., \& Missaglia, N. (2018). India: The Modi Factor. Milan: ISPI.

Tripathi, S. (2017, August 23). Worsening India-China relations may lead to damage to both nations. Retrieved January 18, 2019, from Asia Times: http://www.atimes.com/worsening-india-china-relations-may-lead-damage-nations/

Varma, G. (2017, December 12). Gujarat is missing its CM Narendra Modi. Retrieved December 5, 2018, from Live https://www.livemint.com/Politics/WmdGjBARXh21RFkbX7cfpK/Gujarat-is-missingits-CM-Narendra-

Modi.html?utm_source=scroll\&utm_medium=referral\&utm_campaign=scroll

Varma, K. J. (2011, November 9). Narendra Modi seeks Chinese Investments. Retrieved from Livemint: https://www.livemint.com/Politics/jEg5QSoptBPRemtqXWsV5K/NarendraModi-seeks-Chinese-investments.html

Winger, G. (2014). The Velvet Gauntlet: a Theory of Defense Diplomacy. Retrieved December 16, 2018, from Institute for Human Sciences: http://www.iwm.at/publications/5-junior-visiting-fellows-conferences/vol-xxxiii/thevelvet-gauntlet/

Xinhua. (2015, May 15). Hometown Diplomacy highlights Modi's Xi'an Tour. Retrieved January 14, 2019, from Xinhua: http://www.xinhuanet.com/english/201505/15/c_134239928.htm

Zhaohui, L. (2017, Juni 8). Remarks by H.E. Ambassador Luo Zhaohui at the United Service Institution of India. Retrieved from Chinese Embassy Website: http://in.chineseembassy.org/eng/gdxw/t1459430.htm 